\title{
Other articles noted
}

T he purpose and procedure section in each issue of Evidence-Based Medicine describes the criteria for selecting articles for inclusion. The journals read are also listed in each issue. All articles that meet our criteria in the reviewed journals are cited in Evidence-Based Medicine, but there is not enough space to abstract them all. The following articles passed all criteria but were not abstracted. Practising clinicians rated them for clinical relevance and newsworthiness, and the mean scores are displayed. A fuller list of articles and a sample of the rating form are available on the Evidence-Based Medicine web site (www.evidence-basedmedicine.com/cgi/content/full/10/5/el).

\section{THERAPEUTICS}

McAlister F, Ezekowitz J, Wiebe N, et al. Cardiac resynchronization therapy for congestive heart failure. Evid Rep Technol Assess (Summ) 2004; 106:1-8.

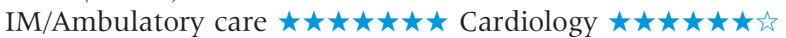

Kotowska M, Albrecht P, Szajewska H. Saccharomyces boulardii in the prevention of antibiotic-associated diarrhoea in children: a randomized double-blind placebo-controlled trial. Aliment Pharmacol Ther 2005;21:583-90.

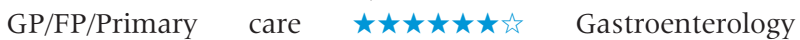

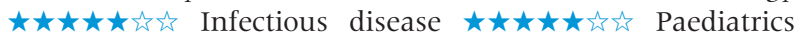

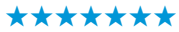

Borstad GC, Bryant LR, Abel MP, et al. Colchicine for prophylaxis of acute flares when initiating allopurinol for chronic gouty arthritis. J Rheumatol 2004;31:2429-32.

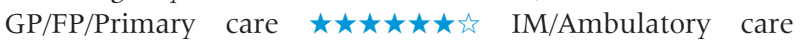

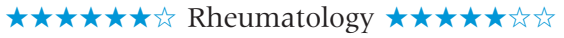

Rojas MP, Telaro E, Russo A, et al. Follow-up strategies for women treated for early breast cancer. Cochrane Database Syst Rev 2005; ( 1):CD001768.

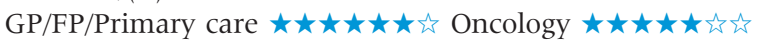

Shaukat A, Scouras N, Schunemann HJ. Role of supplemental calcium in the recurrence of colorectal adenomas: a metaanalysis of randomized controlled trials. Am J Gastroenterol 2005;100:390-4.

GP/FP/Primary care $\star \star \star \star \star \star \star \star ฝ$ IM/Ambulatory care

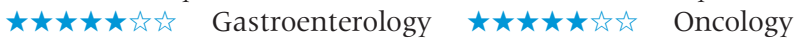

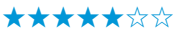

Dorffler-Melly J, Koopman MM, Prins MH, et al. Antiplatelet and anticoagulant drugs for prevention of restenosis/reocclusion following peripheral endovascular treatment. Cochrane Database Syst Rev 2005; (1):CD002071.

GP/FP/Primary care $\star \star \star \star \star \star \star$ is Internal medicine

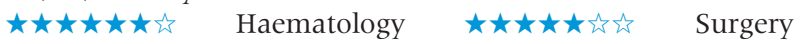

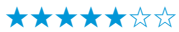

Streppel MT, Arends LR, van 't Veer P, et al. Dietary fiber and blood pressure: a meta-analysis of randomized placebocontrolled trials. Arch Intern Med 2005;165:150-6.

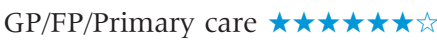

van de Laar FA, Lucassen PL, Akkermans RP, et al. Alphaglucosidase inhibitors for patients with type 2 diabetes: results from a Cochrane systematic review and meta-analysis. Diabetes Care 2005;28:154-63.

GP/FP/Primary care $\star \star \star \star \star \star \star \star$ is IM/Ambulatory care

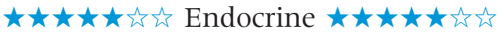

Andersen NH, Poulsen PL, Knudsen ST, et al. Long-term dual blockade with candesartan and lisinopril in hypertensive patients with diabetes: the CALM II study. Diabetes Care 2005;28:273-7.

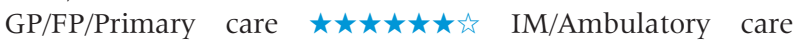

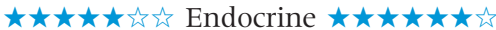

Kar BR, Handa S, Dogra S, et al. Placebo-controlled oral pulse prednisolone therapy in alopecia areata. J Am Acad Dermatol 2005;52:287-90.

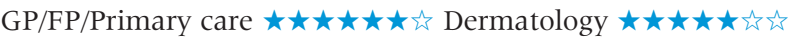

Fergusson D, Doucette S, Glass KC,et al. Association between suicide attempts and selective serotonin reuptake inhibitors: systematic review of randomised controlled trials. 2005;330:396.

GP/FP/Primary care $\star \star \star \star \star \star \star \succsim$ IM/Ambulatory care

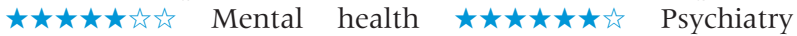

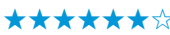

Mendelow AD, Gregson BA, Fernandes HM, et al. Early surgery versus initial conservative treatment in patients with spontaneous supratentorial intracerebral haematomas in the International Surgical Trial in Intracerebral Haemorrhage (STICH): a randomised trial. Lancet 2005;365:387-97.

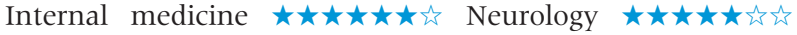

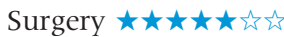

Wong CA, Scavone BM, Peaceman AM, et al. The risk of cesarean delivery with neuraxial analgesia given early versus late in labor. $N$ Engl J Med 2005;352:655-65.

GP/FP/Anaesthesia $\quad \star \star \star \star \star \star \star \star$ is $\quad$ GP/FP/Obstetrics

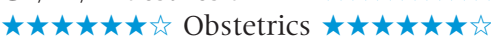

Flather MD, Shibata MC, Coats AJ, et al. Randomized trial to determine the effect of nebivolol on mortality and cardiovascular hospital admission in elderly patients with heart failure (SENIORS). Eur Heart J 2005;26:215-25.

Cardiology $\star \star \star \star \star \star \star \star$ 论

Tharyan P, Adams CE. Electroconvulsive therapy for schizophrenia. Cochrane Database Syst Rev 2005;(2):CD000076.

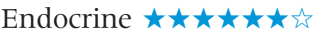

Beck JI, Boothroyd C, Proctor M, et al. Oral anti-oestrogens and medical adjuncts for subfertility associated with anovulation. Cochrane Database Syst Rev 2005; (1):CD002249.

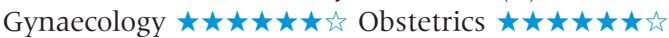

Bradley R, Greene J, Russ E, et al. A multidimensional metaanalysis of psychotherapy for PTSD. Am J Psychiatry 2005; 162:214-27.

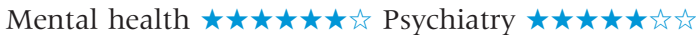

Argyriou AA, Chroni E, Koutras A, et al. Vitamin E for prophylaxis against chemotherapy-induced neuropathy: a randomized controlled trial. Neurology 2005;64:26-31.

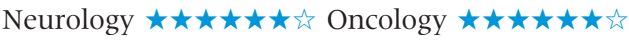


158

Costa J, Espirito-Santo C, Borges A, et al. Botulinum toxin type A versus anticholinergics for cervical dystonia. Cochrane Database Syst Rev 2005;(1):CD004312.

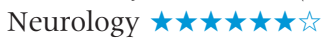

Glazener CM, Evans JH, Peto RE. Alarm interventions for nocturnal enuresis in children. Cochrane Database Syst Rev 2005;(2):CD002911.

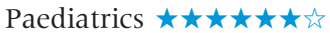

Bellamy N, Campbell J, Robinson V, et al. Intraarticular corticosteroid for treatment of osteoarthritis of the knee. Cochrane Database Syst Rev 2005;(2):CD005328.

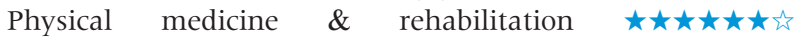

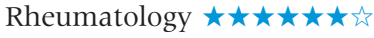

Quinn MA, Conaghan PG, ÒConnor PJ, et al. Very early treatment with infliximab in addition to methotrexate in early, poor-prognosis rheumatoid arthritis reduces magnetic resonance imaging evidence of synovitis and damage, with sustained benefit after infliximab withdrawal: results from a twelve-month randomized, double-blind, placebo-controlled trial. Arthritis Rheum 2005;52:27-35.

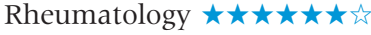

Hirschl M, Katzenschlager R, Francesconi C, et al. Low level laser therapy in primary Raynaud's phenomenon-results of a placebo controlled, double blind intervention study. $J$ Rheumatol 2004;31:2408-12.

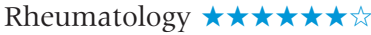

Bucher P, Mermillod B, Gervaz P, et al. Mechanical bowel preparation for elective colorectal surgery: a meta-analysis. Arch Surg 2004;139:1359-64.

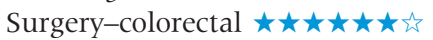

Altunaiji S, Kukuruzovic R, Curtis N, et al. Antibiotics for whooping cough (pertussis). Cochrane Database Syst Rev 2005; ( 1):CD004404.

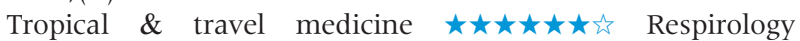

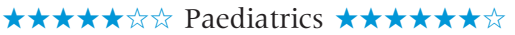

Eisenhut M, Omari AA. Intrarectal quinine for treating Plasmodium falciparum malaria. Cochrane Database Syst Rev 2005; ( 1):CD004009.

Tropical \& travel medicine $\star \star \star \star \star \star \star \star$ 公

Cirillo DJ, Wallace RB, Rodabough RJ, et al. Effect of estrogen therapy on gallbladder disease. JAMA 2005;293:330-9.

GP/FP/Primary care $\star \star \star \star \star \star \star$ 级放 IM/Ambulatory care

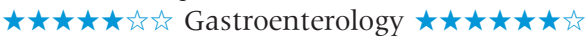

Rubak S, Sandbaek A, Lauritzen $\mathrm{T}$, et al. Motivational interviewing: a systematic review and meta-analysis. $\mathrm{Br} J$ Gen Pract 200555:305-12.

GP/FP/Primary care $\star \star \star \star \star \star \star え え$

Milo G, Katchman EA, Paul M, et al. Duration of antibacterial treatment for uncomplicated urinary tract infection in women. Cochrane Database Syst Rev 2005;(2):CD004682.

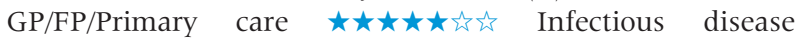

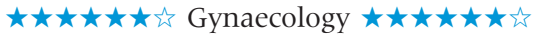

Stiasny-Kolster K, Benes H, Peglau I, et al. Effective cabergoline treatment in idiopathic restless legs syndrome. Neurology 2004;63:2272-9.

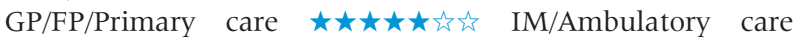

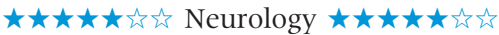

Sowers JR, White WB, Pitt B, et al. The effects of cyclooxygenase-2 inhibitors and nonsteroidal anti-inflammatory therapy on 24-hour blood pressure in patients with hypertension, osteoarthritis, and type 2 diabetes mellitus. Arch Intern Med 2005;165:161-8.

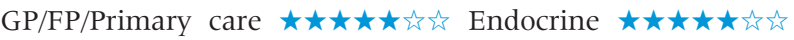

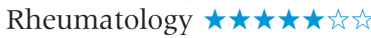

Simoens S, Matheson C, Bond C, et al. The effectiveness of community maintenance with methadone or buprenorphine for treating opiate dependence. Br J Gen Pract 2005;55:139-46. GP/FP/Primary care $\star \star \star \star \star \star \star ⿰ 幺 𠃌$ Mental health

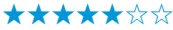

Confalonieri M, Urbino R, Potena A, et al. Hydrocortisone infusion for severe community-acquired pneumonia: a preliminary randomized study. Am J Respir Crit Care Med 2005; 171:242-8.

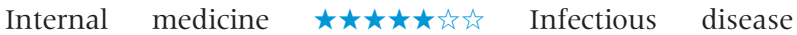

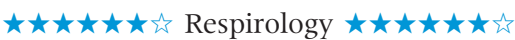

Costa J, Espirito-Santo C, Borges A, et al. Botulinum toxin type A therapy for cervical dystonia. Cochrane Database Syst Rev 2005; ( 1):CD003633.

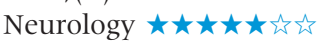

Arrich J, Piribauer F, Map P, et al. Intra-articular hyaluronic acid for the treatment of osteoarthritis of the knee: systematic review and meta-analysis. CMAJ 2005;172:103943.

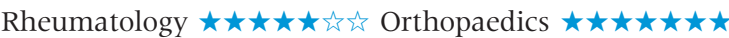

\section{PROGNOSIS}

Heuts PH, de Bie R, Drietelaar M, et al. Self-management in osteoarthritis of hip or knee: a randomized clinical trial in a primary healthcare setting. J Rheumatol 2005;32:543-9.

GP/FP/Primary care $\star \star \star \star \star \star \star \star$ is IM/Ambulatory care

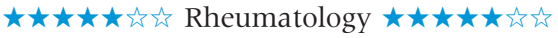

\section{AETIOLOGY}

Martel MJ, Rey E, Beauchesne MF, et al. Use of inhaled corticosteroids during pregnancy and risk of pregnancy induced hypertension: nested case-control study. BMJ 2005;330:230.

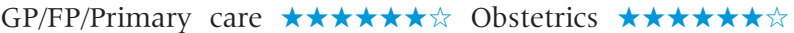

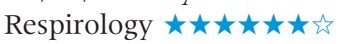

Albert CM, Chae CU, Rexrode KM, et al. Phobic anxiety and risk of coronary heart disease and sudden cardiac death among women. Circulation 2005;111:480-7.

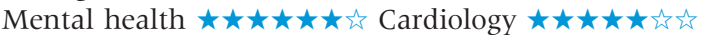

Kragelund C, Gronning B, Kober L, et al. N-terminalpro-Btype natriuretic peptide and long-term mortality in stable coronary heart disease. $N$ Engl J Med 2005;352:666-75.

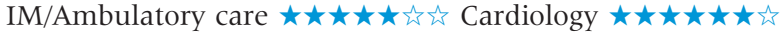

